\title{
Seasonal changes in the concentration and metabolic activity of bacteria and viruses at an Antarctic coastal site
}

\author{
Imojen Pearce ${ }^{1}$, Andrew T. Davidson ${ }^{1, *}$, Elanor M. Bell ${ }^{2}$, Simon Wright ${ }^{1}$ \\ ${ }^{1}$ Australian Antarctic Division, Channel Highway, Kingston, 7050 Tasmania, Australia \\ ${ }^{2}$ Department of Ecology and Ecosystem Modelling, Institute of Biochemistry and Biology, University of Potsdam, \\ Maulbeerallee 2, 14469 Potsdam, Germany
}

\begin{abstract}
Bacteria play a key role in the world's oceans, supporting nutrient remineralisation and mediating carbon transfer. Little is known about annual changes in bacterial concentration, production and metabolism during the extreme seasonal changes in biological productivity in Antarctic waters. We measured rates of bacterial production, concentrations of viruses and bacteria and environmental parameters between February 2004 and January 2005 at an Antarctic coastal site. Concentrations of total bacteria and viruses were obtained using 4',6-diamidino-2-phenylindole (DAPI) and SYBR Green I (Molecular Probes), respectively. Populations of bacteria in different metabolic states were estimated using vital stains. Concentrations of bacteria with intact or compromised plasma membranes were estimated using BacLight (Molecular Probes) and active cells estimated using 6carboxyfluorescein diacetate (6CFDA). Our study showed 6CFDA and BacLight gave rapid and ecologically valuable insights into bacterial physiology, production and growth in natural Antarctic communities that were poorly represented by changes in total cell concentrations. Concentrations of total, active and intact bacteria declined rapidly at the end of summer probably owing to viral infection and microheterotrophic grazing. The decline continued over winter, likely owing to substrate limitation, and concentrations only increased after the phytoplankton bloom in spring and summer. Bacterial abundance was positively correlated with particulate organic carbon (POC) and nitrogen (PON), but not dissolved organic carbon (DOC), reflecting the refractory nature of the DOC pool. Only active and intact bacteria were significantly correlated with concentrations of chl a and rates of bacterial production. Furthermore, the obtained rates of $\left[{ }^{3} \mathrm{H}\right]$ thymidine uptake suggest that bacterial growth rates can be sustained by the populations identified as intact or by active cells alone.
\end{abstract}

KEY WORDS: Antarctic $\cdot$ Bacteria $\cdot$ Viruses $\cdot$ Metabolic activity $\cdot$ DOC

\section{INTRODUCTION}

Because the world's oceans are the principal sink for atmospheric $\mathrm{CO}_{2}$, recent focus on global climate change has directed scientific attention to marine trophodynamics and carbon flux. This research has led to the realisation that the microbial loop is an important mediator of atmospheric $\mathrm{CO}_{2}$ (e.g. Grossmann \& Dieckmann 1994). Heterotrophic marine bacteria are key components of the microbial loop. They remineralise nutrients that support microbial production and transform dissolved organic carbon (DOC) into bacterial biomass supporting bacterivores (Azam 1998).

The contribution of bacterioplankton to nutrient cycling and their role in the microbial loop are largely determined by their metabolic activity (del Giorgio et al. 1996, Smith \& del Giorgio 2003). The carbon and energy source for heterotrophic marine bacterioplankton is inherently variable over space and time in the marine environment (Azam 1998). Extreme fluctuations in productivity in Antarctic waters (Delille 2004) are likely imposing large changes on the availability of 
substrate for bacteria. While bacterial abundance and production in the Southern Ocean are reportedly similar to elsewhere in the world's oceans (Rivkin et al. 1996, Leakey et al. 1996), such studies are largely restricted to summer months. Studies of Antarctic bacterial biomass and production over annual or interannual time-scales are required to accurately determine carbon budgets for these waters (Delille 2004).

It is now recognised that natural communities of marine bacteria contain cells that vary greatly in metabolic state, from 'active' to 'dormant', 'live', 'viable but non-culturable', and 'dead', largely depending on their nutritional status (Smith \& del Giorgio 2003 and references therein). A natural corollary of this realisation is that specific bacterial populations or individual cells would not contribute equally to community growth and production. Though different methods provide differing estimates of the proportion of viable or metabolically active bacteria, they unanimously show that only a fraction of the cells are active (Smith \& del Giorgio 2003), thereby invalidating any assumption that bacteria are a homogeneous community of active cells. Despite this, estimates of bacterial activity in the Southern Ocean have been derived from incorporation rates of radiolabelled amino acids and normalised to concentrations of total bacteria obtained using acridine orange or 4',6-diamidino-2phenylindole (DAPI) (e.g. Billen \& Becquevort 1990, Stewart \& Fritsen 2004). As explicitly stated by Rivkin et al. (1996), this inherently assumes that all bacteria are considered to be physiologically active.

A range of techniques, including vital stains, are now available to estimate the physiological state and metabolic activity of marine bacterioplankton. Most estimates of bacterial metabolism are determined from uptake rates of radiolabelled substrates (Kirchman 2001, Delille 2004), but little is known about the physiological state of cells responsible for bacterial production in Antarctic waters or annual changes in bacterial physiology. Vital stains include 6-carboxyfluorescein diacetate (6CFDA), which stains bacteria expressing high esterase activity (Yamaguchi \& Nasu 1997), 5cyano-2,3-ditolyl tetrazolium chloride (CTC), which stains those cells with active electron transport chains (Sherr et al. 1999), and BacLight, which has been used to estimate concentrations of intact bacteria and those that have compromised (leaky) cell membranes or are dead (Boulos et al. 1999, Davidson et al. 2004). BacLight is comprised of 2 stains: SYTO9, which stains all bacteria, causing them to fluoresce green, and propidium iodide (PI), which penetrates cells with leaky membranes, quenches the fluorescence of SYTO9, and causes them to fluoresce red.

No consensus has been reached on the effectiveness of vital stains at discriminating between physiological states of bacteria. Some authors have found the following: (1) the efficiency of staining can vary; (2) some stains are toxic or inhibit bacterial metabolism; (3) the concentration of metabolically active bacteria varies with the stain used; and (4) stains correlate poorly with rRNA probes, fluorescent in situ hybridization, autoradiography, confocal microscopy and microbial culturing (Karner \& Fuhrman 1997, Smith \& del Giorgio 2003, Pirker et al. 2005). Others have found that stains provide a rapid and ecologically valuable measure of bacterial activity (e.g. del Giorgio et al. 1996, Sherr et al. 1999). Smith \& del Giorgio (2003) argued that such stains provide concentrations of bacteria at different points on the continuum between active and inactive. Studies using these stains have shown that marine bacterioplankton vary greatly in activity and suggest that a small fraction of the bacterial community is often responsible for much of the bacterial production and respiration (del Giorgio et al. 1996, Yamaguchi \& Nasu 1997, Smith 1998, Sherr et al. 1999).

Recently, Davidson et al. (2004) estimated the physiological state of bacterioplankton in the Southern Ocean on a longitudinal transect between Tasmania and Antarctica. Using BacLight, 6CFDA and CTC they showed that, like elsewhere, Antarctic marine bacterioplankton were not homogeneously active. Only around $30 \%$ of the total bacterioplankton community had intact cell membranes and were probably responsible for much of the respiration and remineralisation. However, the physiological states of natural bacterioplankton communities in Antarctic waters have not yet been determined over an annual cycle.

The viability of bacterioplankton can be greatly affected by viral infection. Virioplankton are important determinants of marine microbial composition and trophodynamics, and principal agents of bacterial mortality (Furhman 1999), but little is known of their abundance and role in the Southern Ocean. Based on concentrations of virus-like particles (VLPs) and virus:bacterial ratios (VBRs), they appear to be as important in the Southern Ocean as elsewhere in the world's oceans (Marchant et al. 2000). Guixa-Boixereu et al. (2002) found that viral infection removed 50 to $100 \%$ of bacterial production in the Southern Ocean and resulted in mortality exceeding that of bacterivory. However, studies have been restricted to summer months and nothing is known about annual changes in virioplankton concentrations and interactions with their microbial hosts.

This study reports annual changes in the abundance, production and physiological state of marine bacterioplankton at an Antarctic coastal site in relation to the physical, chemical and biotic environment, including virioplankton. 


\section{MATERIALS AND METHODS}

Sample collection. Sampling was conducted at O'Gorman rocks, approximately $1 \mathrm{~km}$ offshore from the Davis Station, Antarctica $\left(68^{\circ} 35^{\prime} \mathrm{S}, 7^{\circ} 58^{\prime} \mathrm{E}\right)$ (Fig. 1). Samples were taken every 2 wk from 16 February to 23 November 2004, and on 18 December 2004 and 12 and 29 January 2005. Samples from the last 3 sampling dates were returned to Australia for analysis. Measurements of photosynthetically active radiation (PAR), rates of bacterial production and concentrations of active bacteria, chlorophyll a (chl a) and virus-like particles (VLP) were not obtained on these 3 sampling dates.

The water depth at the sampling site was approximately $22 \mathrm{~m}$ and was covered by sea ice from late March to late December 2004. Sea ice thickness was measured every 2 wk (after Heil 2006). Vertical profiles of temperature and PAR were recorded using a YSI 6600 probe (YSI). In addition, temperature and PAR at $5 \mathrm{~m}$ depth was measured daily from 24 May to 23 November 2004 as described by Palethorpe et al. (2004). The mean number of clear-sky hours of sunshine per day was calculated for the period between sampling intervals using data obtained from the Australian Bureau of Meteorology.

Samples were collected from $5 \mathrm{~m}$ depth using a darkened Kemmerer bottle, either from an inflatable rubber boat during ice-free periods, or via a hole drilled through the sea ice. On each sampling occasion, water

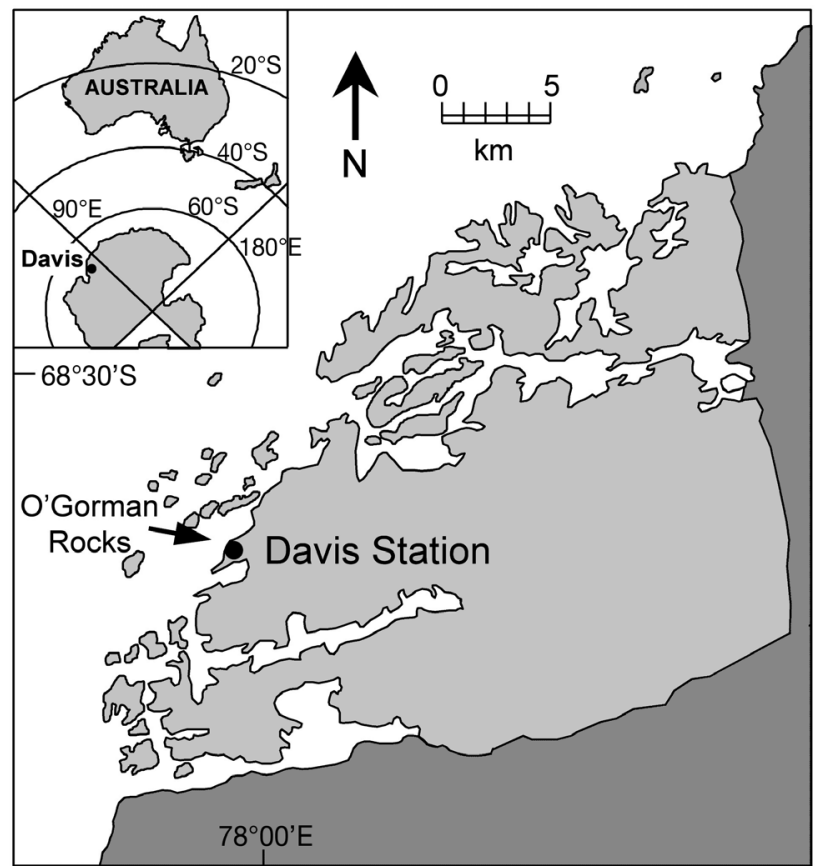

Fig. 1. Davis Station on the east Antarctic coastline, and sample site at O'Gorman Rocks was transferred to 201 polythene carboys, returned to the laboratory under subdued light, maintained in the dark at $2.2 \pm 0.6^{\circ} \mathrm{C}$ and subsampled for analyses.

Organic carbon/nitrogen analyses. All glassware and filters were muffled at $500^{\circ} \mathrm{C}$ for $8 \mathrm{~h}$ prior to use. Forceps and other plasticware were soaked in $10 \%$ Decon 90 (Decon Laboratories) detergent for $>2 \mathrm{~d}$ and thoroughly rinsed in Milli-Q water. Approximately $4 \mathrm{~h}$ after sample collection, a known volume of sample (400 to $900 \mathrm{ml}$ ) was filtered through a muffled $25 \mathrm{~mm}$ GF/F filter until the filter clogged.

The filtrate was collected directly into Whirlpaks (Nasco), frozen at $-20^{\circ} \mathrm{C}$ and returned to Australia to determine concentrations of non-purgable DOC. Samples were thawed, $5 \mathrm{ml}$ decanted into muffled sample vials, acidified with $25 \mu \mathrm{l} 50 \% \mathrm{H}_{3} \mathrm{PO}_{4}$ and sparged for 9 min with high purity nitrogen to remove dissolved inorganic carbon (DIC). Milli-Q blanks (unfiltered) and operational blanks (using Milli-Q filtered as above) were performed at Davis Station, both of which gave DOC concentrations near the limits of detection. Operational blanks were subtracted from the DOC concentrations in sea water samples. Analyses were performed using a Shimadzu TOC 5000 total organic carbon analyser that was calibrated using freshly prepared solutions of potassium hydrogen phthalate (0 to $5.0 \mathrm{mg} \mathrm{C}^{-1}$ ) in Milli-Q water, each of which was acidified and sparged as above. A coefficient of variance < $2 \%$ of the concentration was obtained over 3 to 5 replicate analyses of each sample.

The $25 \mathrm{~mm}$ Whatman GF/F filter (see above) was retained to determine concentrations of particulate organic carbon (POC) and nitrogen (PON). Filters were folded in half, sample inward, and frozen at $-20^{\circ} \mathrm{C}$ until analysis. A muffled glass cap on the end of a syringe was used to punch out $2.69 \mathrm{~mm}$ diameter subsamples from the frozen filters. These were exposed to $\mathrm{HCl}$ fumes in a desiccator for $\geq 12 \mathrm{~h}$ to remove inorganic carbon, dried for $\geq 12 \mathrm{~h}$ at $60^{\circ} \mathrm{C}$ and transferred into ultra light-weight pressed tin capsules (Elemental Microanalysis). The capsules were then crushed and the concentration of POC and PON determined using a Carlo Erba Elemental Analyser at the University of Tasmania.

Pigment analysis. Approximately $3 \mathrm{~h}$ after sample collection, triplicate subsamples of a known volume $(\leq 1 \mathrm{l})$ of sea water were filtered through $13 \mathrm{~mm}$ diameter Whatman GF/F filter and stored frozen at $-80^{\circ} \mathrm{C}$ at Davis Station. These were then transferred to liquid nitrogen during transport to Australia and stored in an Ultra Low (Sanyo) freezer at $-135^{\circ} \mathrm{C}$ until analysed. Pigments were extracted by sonication in $1.8 \mathrm{ml}$ of $\mathrm{MeOH}$, to which $176 \mu \mathrm{g}$ of apo-8'- $\beta$-carotenal (Fluka) was added as an internal standard. The extract was filtered through a $0.45 \mu \mathrm{m}$ inline filter and pigments 
were identified by HPLC using the methods of Zapata et al. (2000). Hardware included a 626 LC pump (Waters), a Waters Symmetry C8 column $(250 \times$ $4.6 \mathrm{~mm}, 5 \mu \mathrm{m}$ bead size), a Waters 996 photodiode array and F1000 fluorescence detectors (Hitachi). Millenium 32 (version 3.05.01) and Waters Empower build 1154 software was used in the acquisition and processing of data. Pigments were identified by comparison with authentic pigment spectra obtained from the Scientific Committee on Oceanic Research (SCOR) reference cultures (Jeffrey \& Wright 1997), and by comparison of retention times of a mixture of standard pigments that was analysed daily. Pigments were quantified following the internal standard method of Mantoura \& Repeta (1997) after isolation of individual pigments from SCOR cultures and spectrophotometric quantification in standard solvents (Jeffrey \& Wright 1997). The mean and standard error of chl a concentration was calculated for each sampling event.

Staining and microscopy. Samples were stained within $2 \mathrm{~h}$ of collection and counts completed within $6 \mathrm{~h}$. The only exceptions were samples collected on 18 December 2004 and 12 and 29 January 2005, which were preserved with $2 \%$ glutaraldehyde and maintained at $4^{\circ} \mathrm{C}$. These samples were returned to Australia, stained and counted within 2 mo of collection. Duplicates were prepared from each sample using each stain.

Concentrations of total bacteria were obtained by adding 3 drops (approx $0.1 \mathrm{ml}$ ) of $100 \mathrm{mg} \mathrm{l}^{-1}$ DAPI stock solution to $4 \mathrm{ml}$ of seawater and staining in the dark at room temperature for 20 to $30 \mathrm{~min}$. Concentrations of bacteria with 'intact' or 'leaky' membranes were estimated by dual staining with BacLight, using $7 \mu \mathrm{l}$ of $20 \mathrm{mM}$ PI and $3 \mu \mathrm{l}$ of $3.34 \mathrm{mM}$ SYTO9 per ml of seawater, followed by incubation in the dark at $\pm 2^{\circ} \mathrm{C}$ of ambient temperature for $30 \mathrm{~min}$. The abundance of total bacteria represents the sum of the number of intact bacteria and those with a compromised cell membrane determined in BacLight-stained samples. Concentrations of metabolically active bacteria were estimated by adding $1 \mathrm{\mu l} \mathrm{ml}^{-1}$ of $1 \%(\mathrm{w} / \mathrm{v})$ 6CFDA in acetone, followed by incubation in the dark at $\pm 2{ }^{\circ} \mathrm{C}$ of ambient temperature for $20 \mathrm{~min}$. Stained samples were then filtered to dryness onto a black $25 \mathrm{~mm}$, $0.22 \mu \mathrm{m}$ polycarbonate Nuclepore filter over $0.8 \mu \mathrm{m}$ backing filter (Durapore).

To determine the total concentration of virus-like particles (VLP), $1 \mathrm{ml}$ of sample was filtered onto a $25 \mathrm{~mm}$, $0.02 \mu \mathrm{m}$ Anodisc filter and the filter was placed onto a drop of $0.01 \%$ final concentration SYBR Green I in the dark for 15 min (Noble \& Fuhrman 1998). Total bacterial abundance was also obtained from the same filter.

Filters were mounted on a microscope slide and a drop of $p$-phenylenediamine antifade placed on the surface and a coverslip added (Noble \& Fuhrman
1998). Counts of stained bacteria and viruses were obtained at 1000× magnification using a Zeiss Axioscop equipped for epifluorescence. UV excitation (filter set 487902 with $365 \mathrm{~nm}$ exciter filter, $395 \mathrm{~nm}$ chromatic beam splitter and $420 \mathrm{~nm}$ barrier filter) was used for DAPI-stained bacteria. Blue light excitation (filter set 487909 with 450 to $490 \mathrm{~nm}$ excitation filter, $510 \mathrm{~nm}$ chromatic beam splitter and $520 \mathrm{~nm}$ barrier filter) was used for SYBR Green I, SYTO9, PI and 6CFDA. Numbers of bacteria or VLP per microscope field were counted from 10 to 20 randomly chosen microscope fields from duplicate filters. Concentrations of stained bacteria and VLP were calculated, and mean and SE computed for each sample time.

Bacterial production. Bacterial production at $5 \mathrm{~m}$ depth at O'Gorman Rocks was determined using the micro-centrifuge method of Kirchman (2001). Concentrations of $\left[{ }^{3} \mathrm{H}\right]$ thymidine and $\left[{ }^{14} \mathrm{C}\right]$ leucine added to production samples were determined using saturation experiments that were conducted in February and June 2004. Saturation for both $\left[{ }^{3} \mathrm{H}\right]$ thymidine and $\left[{ }^{14} \mathrm{C}\right]$ leucine occurred at $30 \mathrm{nM}$ in summer and $35 \mathrm{nM}$ in winter.

Rates of bacterial production obtained from samples incubated in situ at O'Gorman Rocks were not significantly different from those incubated in a laboratory cold room at $1^{\circ} \mathrm{C}$ in the dark $(\mathrm{p}<0.05)$, and the latter was used thereafter. Incubation of bacterial production was begun within $30 \mathrm{~min}$ of sample collection.

Bacterial incorporation rates of thymidine and leucine were used to calculate rates of bacterial cell and biomass production, respectively (after Bjørnsen \& Kuparinen 1991, Grossmann \& Dieckmann 1994, Kirchman 2001). Published conversion factors used to calculate production vary greatly. We used the conservative conversion factors of $1.91 \times 10^{18} \mathrm{cells} \mathrm{mol}^{-1}$ thymidine determined at this site and a conversion factor of $20 \mathrm{fg} \mathrm{C} \mathrm{cell}^{-1}$ (Leakey et al. 1996), which at mean cell volume for this site $\left(0.13{\mu \mathrm{m}^{3}}^{3}\right.$ A Archer et al. 1996) equates to a carbon conversion factor of $0.15 \mathrm{pg} \mathrm{C}$ $\mu^{-3}$. Calculation of bacterial carbon production assumed an intracellular isotope dilution factor of 2 , a molar ratio of leucine:protein of 0.073 and a carbon: protein ratio of 0.86 (Smith \& Azam 1992).

Growth rates $(\mu)$ of total, intact and active bacteria were calculated from the bacterial cell production (above) using the equation (McManus 1993):

$$
\mu=\frac{1}{t} \ln \left(\mathrm{N}_{t} / \mathrm{N}_{0}\right)
$$

where $\mathrm{N}_{0}$ is the concentration of total, intact or active bacteria measured at $\mathrm{O}^{\prime}$ Gorman Rocks at each sample time, $\mathrm{N}_{t}$ is $\mathrm{N}_{0}$ plus the daily cell production calculated from thymidine uptake, and $t=1 \mathrm{~d}$.

Statistical analysis. Abundances of bacteria and viruses were $\log (x+1)$ transformed to normalise the 
distribution of the data and compensate for large differences among stains and sample times (Legendre \& Legendre 1983). Relationships between bacterial and viral abundances, bacterial production and measured physical variables were tested with Pearson's correlation coefficient.

Statistical analyses of bacterial concentrations obtained using DAPI, BacLight, SYBR Green I and 6CFDA were performed using Statistica. Data were analysed by 1-way ANOVA using a generalised linear model (GLM), owing to differing numbers of replicate counts among stains and sample days. Comparison of bacterial concentrations was performed on data pooled over all sampling events and each sampling date, and significant differences were identified using Tukey's post-hoc analysis.

\section{RESULTS}

A strong seasonal variation was observed in all physical and biological parameters measured at O'Gorman Rocks over the year, with the exception of DOC. Seasonal changes in most environmental variables were significantly related, indicating that the physical and biotic environment frequently co-varied over the year (Table 1).

\section{Physical parameters}

Vertical profiles of temperature and salinity obtained on each sampling date showed no physical stratification (data not shown). Sea ice began to form in March, was thickest $(187.5 \mathrm{~cm})$ on 23 November and disappeared on 29 December 2004 (Fig. 2A). Between March and May 2004, PAR at $5 \mathrm{~m}$ depth declined from around 22 (18 to 26) to $0.1 \mu \mathrm{mol} \mathrm{m} \mathrm{m}^{-2} \mathrm{~s}^{-1}$ and hours of clear sky sunshine declined from around 6.9 to $<1 \mathrm{~h}$ $\mathrm{d}^{-1}$. The sun did not rise above the horizon from 27 May to 7 August 2004 and PAR at $5 \mathrm{~m}$ remained below the limits of detection until late August. PAR

Table 1. Pearson's correlation coefficient (r) between measured environmental and biological variables. Significant values $(p<0.05)$ in bold, degrees of freedom in parentheses. Hours of light refers to sunlight

\begin{tabular}{|lrrrrrr|}
\hline \multicolumn{1}{c}{$\begin{array}{c}\text { Water } \\
\text { temperature } \\
\left({ }^{\circ} \mathrm{C}\right)\end{array}$} & $\begin{array}{r}\text { Hours of } \\
\text { sunlight }\end{array}$ & $\begin{array}{c}\text { Ice } \\
\text { thickness }\end{array}$ & POC & PON & DOC \\
\hline Chl $a$ & $\mathbf{0 . 7 1}(19)$ & $\mathbf{0 . 8 8}(19)$ & $-0.25(19)$ & $\mathbf{0 . 5 7}(19)$ & $\mathbf{0 . 6 4}(19)$ & $0.15(19)$ \\
DOC & $-0.13(22)$ & $-0.08(22)$ & $-0.03(22)$ & $-0.08(22)$ & $-0.15(22)$ & \\
PON & $\mathbf{0 . 7 8}(22)$ & $\mathbf{0 . 7 1}(22)$ & $-\mathbf{0 . 4 9}(22)$ & $\mathbf{0 . 9 7}(22)$ & & \\
POC & $\mathbf{0 . 7 4}(22)$ & $\mathbf{0 . 7 1}(22)$ & $\mathbf{- 0 . 4 7}(22)$ & & & \\
Ice thickness & $\mathbf{- 0 . 6 5}(22)$ & $-0.15(22)$ & & & & \\
Hours of light & $\mathbf{0 . 6 8}(22)$ & & & & & \\
\hline
\end{tabular}
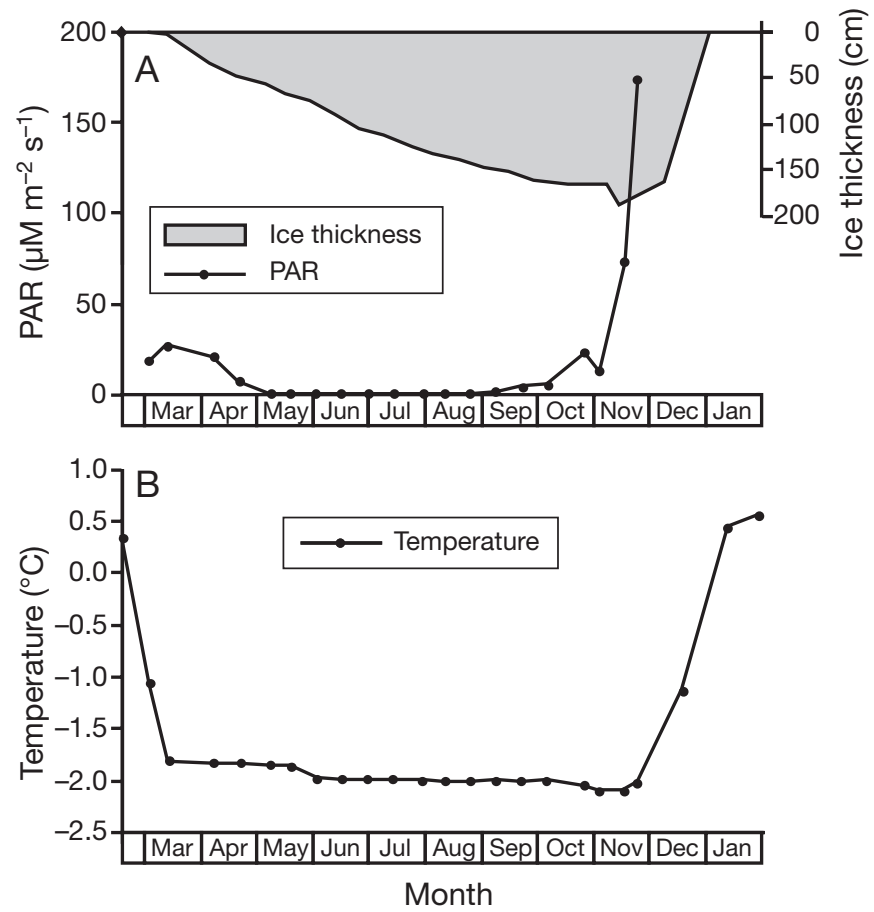

Fig. 2. Physical parameters measured at O'Gorman Rocks between February 2004 and January 2005: (A) ice thickness and PAR, and (B) temperature

then increased in October and November, reaching $172 \mu \mathrm{mol} \mathrm{m} \mathrm{m}^{-2} \mathrm{~s}^{-1}$ on 21 November 2004. Owing to equipment malfunction, PAR was not measured between 23 November 2004 and 29 January 2005. Sea water temperature at $5 \mathrm{~m}$ ranged from $-2.1^{\circ} \mathrm{C}$ on 25 October 2004 to $0.5^{\circ} \mathrm{C}$ on 29 January 2005 (Fig. 2B).

\section{Organic carbon and nitrogen}

Concentrations of POC varied considerably, reaching $1120 \mu \mathrm{M}$ on $12 \mathrm{March}$, declining to around $170 \mu \mathrm{M}$ over the austral winter and increasing again on 16 November 2004 (Fig. 3A). PON concentrations ranged from $8.0 \mu \mathrm{M}$ on 2 August to $224 \mu \mathrm{M}$ on 18 December 2004. The carbon:nitrogen (C:N) ratio was around 5 during spring and autumn but ranged from around 8 to 24 in mid to late winter (Fig. 3A).

In contrast, concentrations of DOC varied between 89 and $170 \mu \mathrm{M}$, but showed no clear seasonal pattern (Fig. 3B). Highest concentrations were observed during mid winter, when DOC concentrations increased around $30 \%$ on 29 July and 7 September 2004. 

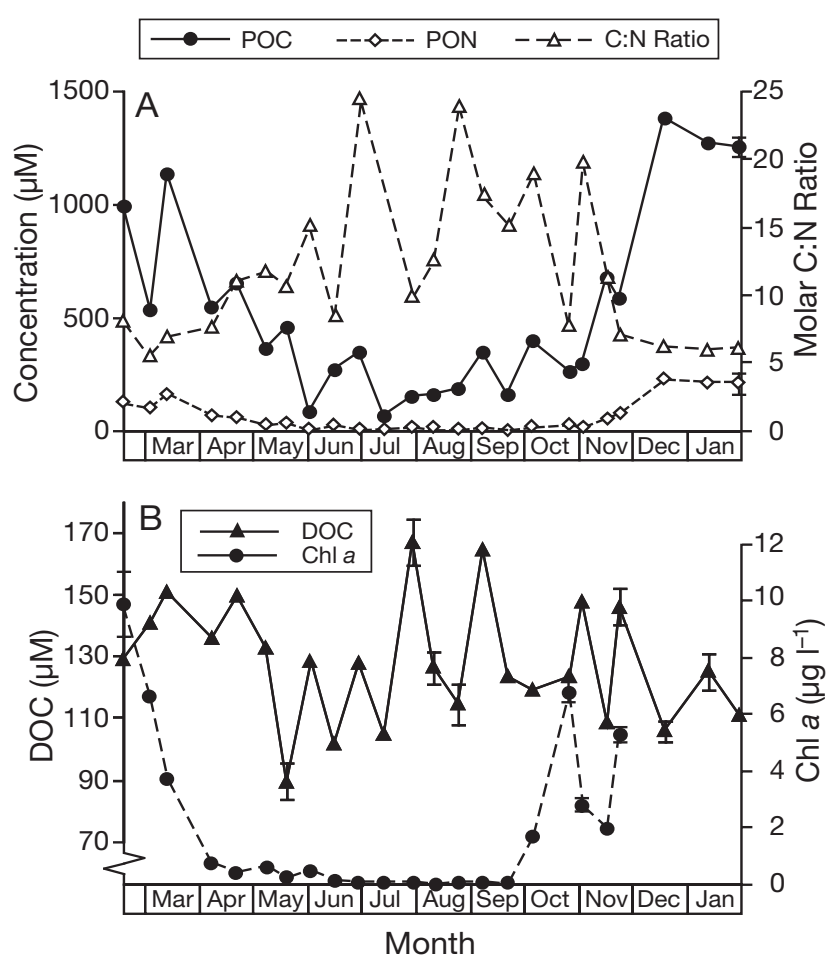

Fig. 3. Concentrations of (A) POC, PON and the C:N ratio, and (B) concentrations of DOC and Chl a. Errors bars: $\pm 1 \mathrm{SE}$ (not presented when smaller than data symbols)

\section{Chlorophyll}

Mean chl a concentration was $9.9 \mu \mathrm{g}^{-1}$ in mid February but rapidly declined in March, continued to decline during April and May, and remained very low over the remainder of winter $\left(<0.03\right.$ to $\left.0.13 \mu \mathrm{g} \mathrm{l}^{-1}\right)$ (Fig. 3B). A peak in chl a of $6.8 \mu \mathrm{g} \mathrm{l}^{-1}$ occurred on 25 October 2004, coinciding with increased concentrations of the ice-associated diatoms Entomoneis sp. and Navicula spp. (data not shown). Concentrations then declined to around $2 \mu \mathrm{g} \mathrm{l^{-1 }}$, but increased to $5.3 \mu \mathrm{g} \mathrm{l^{-1 }}$ on 23 November 2004.

\section{Viruses}

Concentrations of VLP increased to $2.12 \times 10^{10} \mathrm{l}^{-1}$, and the VBR reached 21.4 on 2 March 2004 but declined rapidly thereafter (Fig. 4). The abundance of VLP continued to decline over the remainder of winter and reached a minimum of $0.13 \times 10^{10} \mathrm{l}^{-1}$ and VBR of 3.4 on 5 October 2004. The abundance of VLP was positively related to the abundance of total, intact and active bacteria, but not to chl a or DOC (Table 2). Viral abundance was also positively correlated with environmental variables including ice thickness, temperature and concentrations of PON and POC.

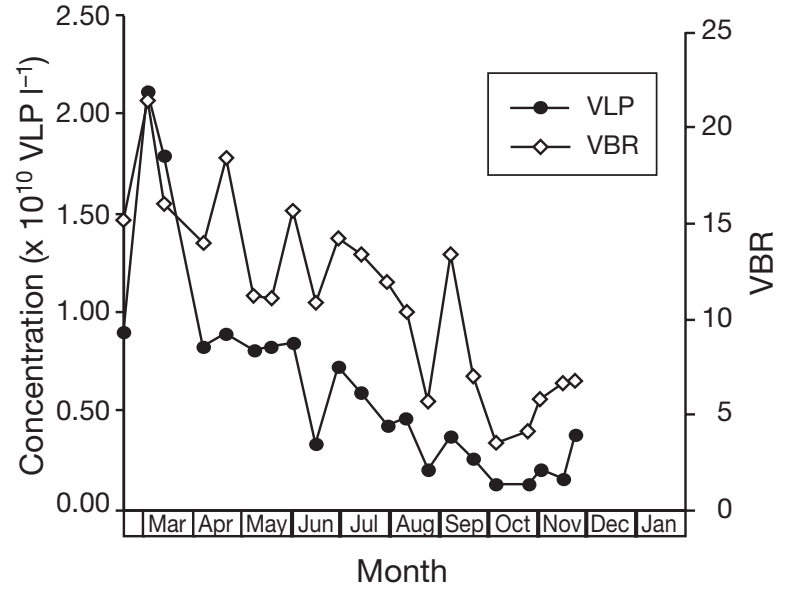

Fig 4. Virus to bacterial ratio (VBR) and concentration of virus-like particles (VLP). SE was always smaller than data symbols

\section{Bacterial abundance}

Total bacteria

Estimates of total bacterial abundance using 3 different stains are shown in Fig. 5. ANOVA using data pooled over the entire study period showed that total bacterial abundance obtained using DAPI, BacLight and SYBR Green I did not significantly differ overall (Table 3). Concentrations obtained using DAPI were on average 15 and $29 \%$ higher than those obtained using SYBR Green and BacLight (Table 3, Fig. 5), respectively. ANOVA at each sample time showed that concentrations rarely differed significantly (Table 4).

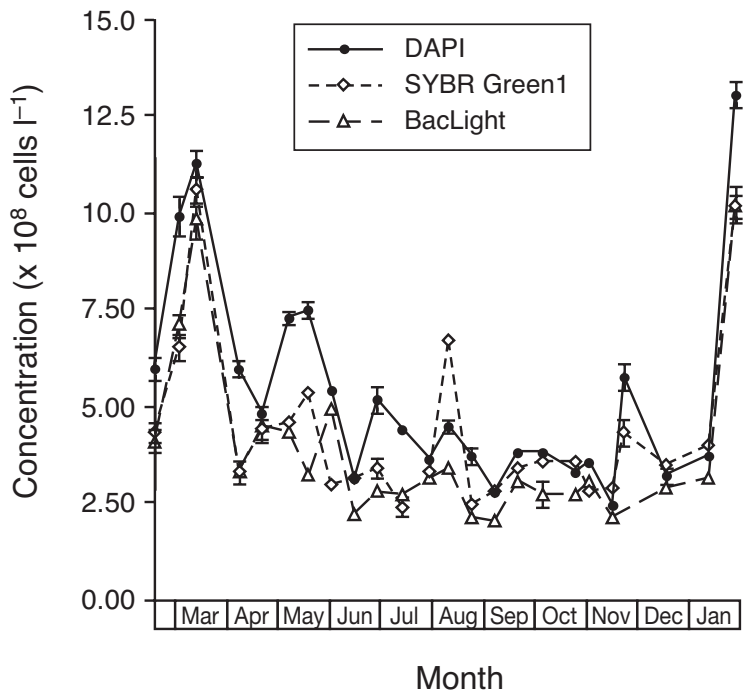

Fig. 5. Concentrations of total bacteria obtained using the nucleic acid stains DAPI, SYBR Green I and BacLight. Errors bars: \pm 1 SE (not presented when smaller than data symbols) 
Table 2. Pearson's correlation coefficient (r) between viral and bacterial concentrations (latter assessed using DAPI, SYBR Green I, BacLight, PI, SYTO9 and 6CFDA), bacterial production, and measured environmental and biological parameters. BP (leu) and BP (thy): rates of bacterial production obtained using leucine and thymidine, respectively. Significant values $(p<0.05)$ in bold, degrees of freedom in parentheses

\begin{tabular}{|c|c|c|c|c|c|c|c|c|c|}
\hline & DAPI & $\begin{array}{l}\text { SYBR } \\
\text { Green I }\end{array}$ & BacLight & PI & SYTO9 & 6CFDA & $\begin{array}{l}\text { Virus } \\
\text { conc. }\end{array}$ & BP (thy) & BP (leu) \\
\hline Chl a & 0.31 (19) & 0.33 (19) & 0.38 (19) & 0.32 (19) & 0.63 (19) & 0.48 (19) & 0.13 (19) & 0.73 (19) & 0.77 (19) \\
\hline Ice thickness & $-\mathbf{0 . 7 1}(22)$ & $-0.57(22)$ & $-\mathbf{0 . 7 3}(22)$ & $-\mathbf{0 . 5 2}(22)$ & $-\mathbf{0 . 6 4}(22)$ & $-\mathbf{0 . 5 9}(19)$ & $-\mathbf{0 . 8 8}(19)$ & -0.44 (19) & $-0.39(19)$ \\
\hline Sunlight & $0.11(22)$ & $0.25(22)$ & $0.25(22)$ & $0.04(22)$ & $\mathbf{0 . 6 2}(22)$ & 0.43 (19) & $-0.12(19)$ & 0.75 (19) & $0.76(19)$ \\
\hline Water temp & $0.38(22)$ & $0.42(22)$ & $0.44(22)$ & $0.1(22)$ & $\mathbf{0 . 8}(22)$ & $0.53(19)$ & 0.44 (19) & 0.89 (19) & 0.91 (19) \\
\hline DOC & $0.04(22)$ & $0.06(22)$ & $0.2(19)$ & $0.37(22)$ & $-0.19(22)$ & $-0.01(19)$ & 0.22 (19) & 0.09 (19) & 0.03 (19) \\
\hline PON & $0.36(22)$ & $0.51(22)$ & $0.49(22)$ & $0.21(22)$ & $0.75(22)$ & 0.7 (19) & 0.7 (19) & $0.53(19)$ & 0.5 (19) \\
\hline POC & $0.33(22)$ & $\mathbf{0 . 5 1}(22)$ & $\mathbf{0 . 4 5}(22)$ & $0.2(22)$ & $\mathbf{0 . 6 7}(22)$ & $\mathbf{0 . 6 9}(19)$ & 0.7 (19) & $0.5(19)$ & $0.5(19)$ \\
\hline BP (leu) & 0.32 (19) & 0.19 (19) & 0.25 (19) & 0.16 (19) & 0.62 (19) & 0.56 (19) & 0.31 (19) & 0.96 (19) & \\
\hline BP (thy) & 0.35 (19) & 0.17 (19) & 0.25 (19) & 0.18 (19) & 0.58 (19) & 0.55 (19) & 0.35 (19) & & \\
\hline Virus conc. & 0.85 (19) & 0.6 (19) & $0.78(19)$ & $0.71(19)$ & 0.57 (19) & $0.52(19)$ & & & \\
\hline 6CFDA & $\mathbf{0 . 6 1}(19)$ & 0.36 (19) & 0.54 (19) & 0.49 (19) & $\mathbf{0 . 6 2}(19)$ & & & & \\
\hline SYTO9 & $\mathbf{0 . 6}(22)$ & $0.47(22)$ & $0.65(22)$ & $0.34(22)$ & & & & & \\
\hline PI & $\mathbf{0 . 8 5}(22)$ & $0.77(22)$ & $\mathbf{0 . 9 2}(22)$ & & & & & & \\
\hline SYBR Green I & $0.8(22)$ & & & & & & & & \\
\hline
\end{tabular}

Concentrations of DAPI-stained bacteria increased to $11.2 \times 10^{8}$ cells $l^{-1}$ in mid March 2004 (Fig. 5), declined to around $3.5 \times 10^{8}$ cells $^{-1}$ during mid to late winter, briefly increased in November and reached $13.0 \times 10^{8}$ cells $1^{-1}$ on 29 January 2005. Concentrations of SYBR Green I- and BacLight-stained bacteria, though lower, followed a similar trend.

Total bacterial concentrations obtained using DAPI, SYBR Green I and BacLight were negatively related to ice thickness and positively related to 6CFDA-, PI- and SYTO9-stained bacteria (Table 2). However, only concentrations obtained using SYBR Green I and BacLight were significantly correlated with temperature and concentrations of POC and PON (Table 1).

\section{Intact and active bacteria}

Most bacteria were stained by PI, suggesting they had compromised cell membranes (Fig. 6A). Overall,

Table 3. Probabilities of significant differences between bacterial concentrations obtained using stains for total (DAPI, SYBR Green I and BacLight), intact (SYTO9) and active (6CFDA) bacteria, derived from ANOVA of bacterial concentrations pooled over all sampling events. Degrees of freedom $=2799$. Significant values $(\mathrm{p}<0.05)$ in bold

\begin{tabular}{|lccccc|}
\hline & DAPI & $\begin{array}{c}\text { SYBR } \\
\text { Green I }\end{array}$ & BacLight & PI & SYTO9 \\
\hline SYBR Green I & 0.70 & & & & \\
BacLight & $\mathbf{0 . 0 0 7}$ & 0.44 & & & \\
PI & $\mathbf{0 . 0 0 0 6}$ & 0.15 & 0.99 & & \\
SYTO9 & $\mathbf{0 . 0 0 0 0 2}$ & $\mathbf{0 . 0 0 0 0 2}$ & $\mathbf{0 . 0 0 0 0 2}$ & $\mathbf{0 . 0 0 0 0 2}$ & \\
6CFDA & $\mathbf{0 . 0 0 0 0 2}$ & $\mathbf{0 . 0 0 0 0 2}$ & $\mathbf{0 . 0 0 0 0 2}$ & $\mathbf{0 . 0 0 0 0 2}$ & $\mathbf{0 . 0 0 0 0 2}$ \\
\hline
\end{tabular}

their concentration did not differ significantly from concentrations of total bacteria obtained using SYBR Green I and BacLight, but were significantly less than those obtained using DAPI (Table 3). Concentrations of PI-stained (leaky) bacteria increased in autumn, reaching $9.27 \times 10^{8}$ cells $\mathrm{l}^{-1}$ in mid March, and varied between 1.82 and $4.33 \times 10^{8}$ cells $~^{-1}$ until spring when 2 peaks were observed in late November and January (Fig. 6A).

The abundance of intact and active bacteria were significantly lower than the concentration of total and leaky bacteria (Table 3, Figs. 5 \& 6). Those considered intact (stained only with SYTO9) comprised up to 1.35 $\times 10^{8}$ cells $1^{-1}$ or $18.7 \%$ of total (DAPI-stained) bacteria in late summer 2004. Their concentrations fell during March, reaching $8.2 \times 10^{6}$ cells $\mathrm{l}^{-1}$ and comprising only $1.8 \%$ of the total bacterial abundance in mid August. The abundance of intact bacteria remained low until late spring then increased to a peak of $4.99 \times 10^{8}$ cells $\mathrm{l}^{-1}$ in mid summer, when they comprised around $33 \%$ of total bacterial abundance (Fig. 6A).

The abundance of highly active bacteria (6CFDA-stained) followed a similar seasonal trend to that of intact cells (Fig. 6B) but was frequently significantly lower (Table 3$)$. The highest concentrations $\left(6.36 \times 10^{7}\right.$ cells $\left.\mathrm{l}^{-1}\right)$ occurred in late summer. Though variable, concentrations of active bacteria then declined, reaching $3.78 \times 10^{6}$ cells $\mathrm{l}^{-1}$ on 10 August 2004. With one exception at the end of August, concentrations remained low, then increased in late spring (Fig. 6B). 
Table 4. Probabilities of significant differences between total bacterial concentrations on each sample date obtained using DAPI, SYBR Green I and BacLight. Numbers 1 to 24 represent sequential sampling events through the season: $1=16$ Feb $2004 ; 24=29$ Jan 2005. Significant values $(p<0.05)$ in bold, degrees of freedom in parentheses

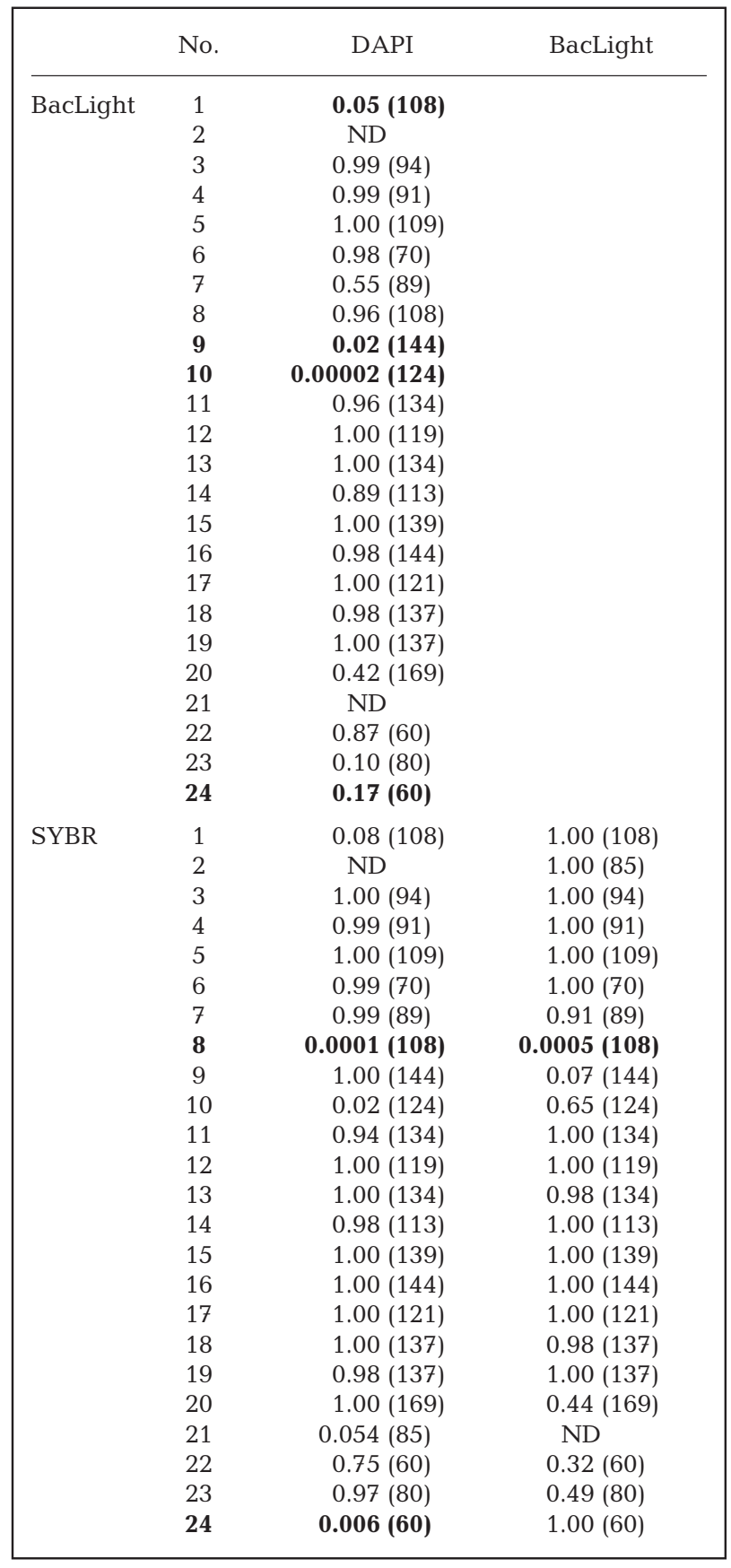

The abundance of both 6CFDA- and SYTO9-stained bacteria was significantly correlated with chl a concentration. However, the abundance of total bacteria obtained using DAPI, SYBR Green I or BacLight was not correlated with chl a (Table 2).
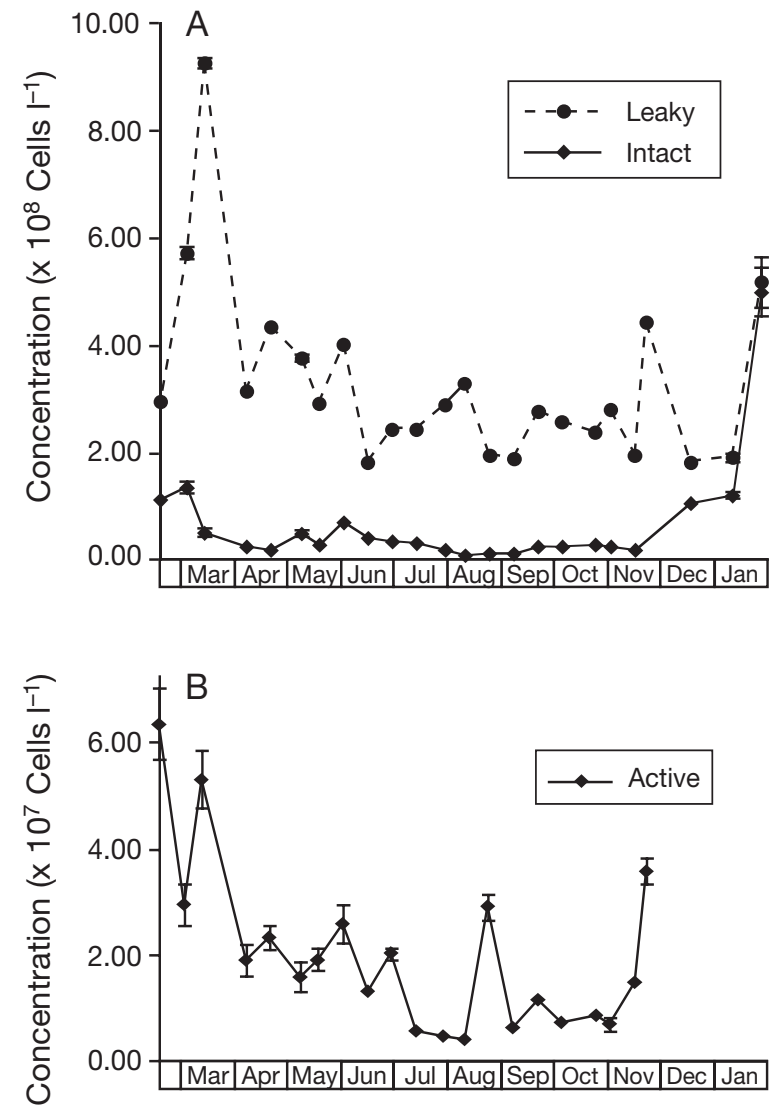

Month

Fig. 6. Concentrations of bacteria that were (A) intact (SYTO9-stained) or leaky (permeable to PI), and (B) active (6CFDA-stained). Errors bars: $\pm 1 \mathrm{SE}$ (not presented when smaller than data symbols)

\section{Bacterial production}

Bacterial production rates of carbon and cells were highly correlated with each other and showed a strong seasonal cycle (Fig. 7). Both rates of production were highest on 16 February 2004, being $2.46 \mu \mathrm{g}$ $\mathrm{C}^{-1} \mathrm{l}^{-1} \mathrm{~h}^{-1}$ and $9.79 \times 10^{6}$ cells $\mathrm{l}^{-1} \mathrm{~h}^{-1}$, but declined rapidly in March. Production continued to decline over autumn and winter, and remained low (below $0.2 \mu \mathrm{g} \mathrm{C}^{-1} \mathrm{l}^{-1} \mathrm{~h}^{-1}$ and $0.55 \times 10^{6}$ cells $\mathrm{l}^{-1} \mathrm{~h}^{-1}$ ) until late spring. The increase in bacterial production in spring was approximately 5 wk after the OctoberNovember peak in chl $a$, but coincided with a second increase in chl $a$, increases in POC and PON, and a decreased POC:PON ratio on 23 November 2004 (Fig. 7). Rates of bacterial production showed significant positive correlation with the abundance of both active and intact bacteria, but not with total bacterial abundance (using either DAPI, SYBR Green I or BacLight) (Table 1). 


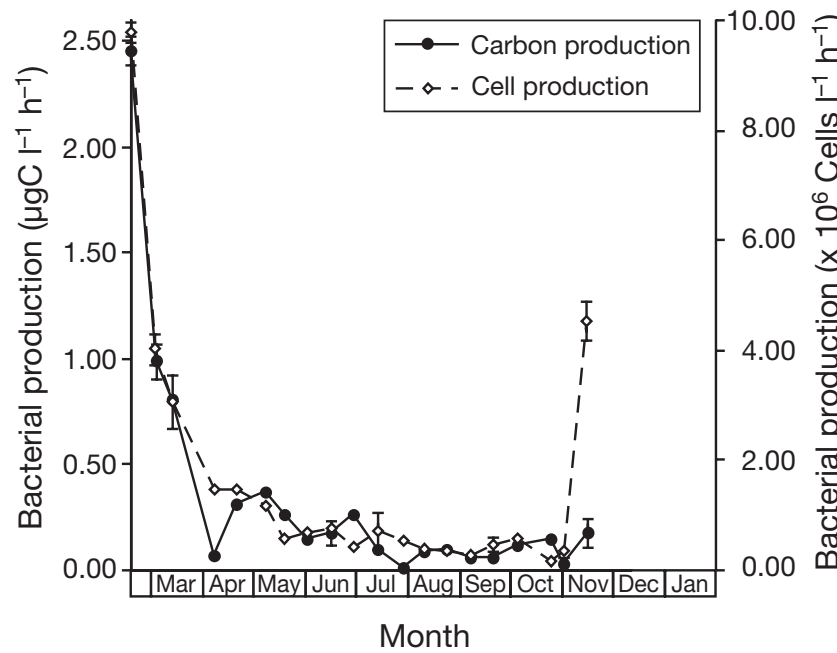

Fig. 7. Rates of bacterial carbon and cell production obtained from uptake rates of $\left[{ }^{14} \mathrm{C}\right]$ leucine and $\left[{ }^{3} \mathrm{H}\right]$ thymidine, respectively. Errors bars: \pm 1 SE (not presented when smaller than data symbols)

Normalisation of rates of bacterial cell production to the abundance of intact (SYTO9-stained) and active (6CFDA-stained) bacteria resulted in growth rates around 9 and 15 times higher, respectively, than that of total bacteria (Table 5). Based on total bacterial abundance, mean annual growth rate was $0.06 \pm 0.02 \mathrm{~d}^{-1}$ and ranged from $0.33 \mathrm{~d}^{-1}$ in late summer (16 February

Table 5. Growth rates of total (DAPI-stained), intact (SYTO9stained using BacLight) or active (6CFDA-stained) bacteria required to support cell production calculated from rates of $\left[{ }^{3} \mathrm{H}\right]$ thymidine uptake

\begin{tabular}{|lccc|}
\hline $\begin{array}{l}\text { Date } \\
(2004)\end{array}$ & $\begin{array}{c}\text { Total } \\
\text { bacteria } \\
\left(\mathrm{d}^{-1}\right)\end{array}$ & $\begin{array}{c}\text { Intact } \\
\text { bacteria } \\
\left(\mathrm{d}^{-1}\right)\end{array}$ & $\begin{array}{c}\text { Active } \\
\text { bacteria } \\
\left(\mathrm{d}^{-1}\right)\end{array}$ \\
\hline 16 Feb & 0.332 & 0.141 & 0.792 \\
$2 \mathrm{Mar}$ & 0.093 & 0.050 & 0.729 \\
$6 \mathrm{Apr}$ & 0.117 & 0.199 & 0.819 \\
20 Apr & 0.070 & 0.126 & 0.401 \\
7 May & 0.047 & 0.049 & 0.543 \\
18 May & 0.036 & 0.071 & 0.387 \\
1 Jun & 0.024 & 0.014 & 0.156 \\
15 Jun & 0.051 & 0.028 & 0.340 \\
29 Jun & 0.035 & 0.040 & 0.257 \\
13 Jul & 0.021 & 0.023 & 0.454 \\
30 Jul & 0.047 & 0.063 & 0.811 \\
10 Aug & 0.027 & 0.101 & 0.721 \\
24 Aug & 0.025 & 0.053 & 0.099 \\
7 Sep & 0.027 & 0.044 & 0.338 \\
21 Sep & 0.017 & 0.020 & 0.174 \\
5 Oct & 0.029 & 0.031 & 0.401 \\
25 Oct & 0.039 & 0.033 & 0.414 \\
2 Nov & 0.010 & 0.010 & 0.158 \\
16 Nov & 0.031 & 0.032 & 0.159 \\
23 Nov & 0.174 & & 0.690 \\
\hline
\end{tabular}

$2004)$ to around $0.02 \mathrm{~d}^{-1}$ in winter and early spring (1 June to 2 November 2004). Based on the abundance of intact bacteria, growth rates averaged $0.56 \pm 0.12 \mathrm{~d}^{-1}$ and ranged from $1.40 \mathrm{~d}^{-1}$ in autumn (6 April 2004) to $0.25 \mathrm{~d}^{-1}$ in late winter (21 September 2004), while growth rates based on the number of active bacteria averaged $0.95 \pm 0.10 \mathrm{~d}^{-1}$ and ranged from $1.58 \mathrm{~d}^{-1}$ in autumn (6 April 2004) to $0.28 \mathrm{~d}^{-1}$ in late winter (24 August 2004).

\section{DISCUSSION}

Several comprehensive studies of Antarctic bacterioplankton have been performed, yet there is little agreement on the principal factors regulating bacterial growth (Ducklow et al. 2001), and very few of these studies encompass winter (Mordy et al. 1995, Scott et al. 2000). This study found large seasonal variation in bacterioplankton abundance in Antarctic coastal waters that correlated with seasonal changes in the physical and biological environment. Different populations within the bacterioplankton were distinguished based on their characteristics in response to a range of vital stains. The characteristics of these populations, and their responses to environmental stimuli, are discussed in the following sections.

\section{Effectiveness of stains}

\section{Stains for total bacteria}

Ideally, stains for total bacterial counts should stain all bacteria irrespective of their metabolic state. Though rarely significant, concentrations of total bacteria obtained using DAPI were on average 15 and $29 \%$ higher than those obtained with SYBR Green I and BacLight, respectively. The nature of these DAPIstained cells warrants further investigation. In particular, it would be useful to know whether they represent different physiological states or taxa that are not permeable to SYBR Green I and BacLight, 'ghost' cells without a genome (Zweifel \& Hagstöm 1995) or the remains of processes such as grazing or viral attack.

Stains for active, intact and leaky bacteria

We identified active bacteria based on their ability to take up and enzymatically hydrolyse the stain 6CFDA. Intact and leaky bacteria were distinguished by their differential uptake of BacLight components. However, such stains do not accurately discriminate bacterial cells that are live, dead, intact and active. Estimates of 
the active bacterial abundance obtained using stains can be much less than those using RNA probes, fluorescent in situ hybridization and autoradiography (e.g. Karner \& Fuhrman 1997, Smith \& del Giorgio 2003). Furthermore, most bacteria stained by PI reportedly assimilate radiolabelled substrates (Pirker et al. 2005). Like Smith \& del Giorgio (2003), we interpret bacteria stained as active, intact or leaky as indicating different points along the metabolic continuum between active and inactive.

The proportion of total (DAPI-stained) bacteria that were identified as leaky ranged from $40 \%$ in summer to around $80 \%$ in winter, while intact bacteria comprised 38 to $1.8 \%$ in summer and winter, respectively. Clearly, the 'active' and 'intact' categories overlap, but we found that the abundance of active cells was significantly lower than that of intact bacteria, comprising approximately $60 \%$ of intact cells, or about $3.6 \%$ of the total (DAPI-stained) bacterial concentration. Davidson et al. (2004) reported similarly low proportions of intact and active bacteria in Antarctic waters using 6CFDA and BacLight.

Our results suggest that intact and active bacteria were responsible for much of the bacterial activity in these coastal Antarctic waters. We found that concentrations of intact and active bacteria correlated with rates of bacterial production, whereas concentrations of total bacteria did not. Similarly, using CTC, Sherr et al. (1999) found strong correlation between bacterial activity and the rate of bacterial production, and Smith (1998) found better correlation between rates of bacterial respiration and active bacteria than total bacterial abundance.

Numbers of intact and active bacteria alone were sufficient to explain the rates of bacterial cell production we observed. When rates of cell production were normalised to total bacterial abundance, bacterial growth rates of 0.01 to $0.33 \mathrm{~d}^{-1}$ were calculated. These rates are quite low but comparable with those recorded by Grossmann \& Dieckmann (1994) and Ducklow et al. (2001) in the Weddell and Ross Seas, respectively, who also normalised to total bacterial abundance. However, normalization to concentrations of intact and active bacteria gave maximum doubling rates of 1.4 and $1.6 \mathrm{~d}^{-1}$, respectively. Bacterial growth rates from 0.01 to $2 \mathrm{~d}^{-1}$ have been reported for Antarctic waters at temperatures of $-1.5^{\circ} \mathrm{C}$, only $0.1^{\circ} \mathrm{C}$ higher than the mean recorded in our study (e.g. Kottmeier \& Sullivan 1988, Rivkin et al. 1991). Thus, concentrations of intact and active bacteria appear sufficient to sustain the rates of bacterial cell production measured during our study. Furthermore, the lack of correlation between total bacterial abundance and rates of production suggests that the contribution of leaky or inactive bacteria to bacterial production was small.

\section{Seasonal changes in bacterioplankton and viruses}

The abundance of total bacteria we measured were similar to those seen elsewhere in Antarctic waters (e.g. Heinänen et al. 1997, Monticelli et al. 2003) and previously reported at this site (Gibson et al. 1990, Davidson \& Marchant 1992, Leakey et al. 1996, Scott et al. 2000). We were unable to identify the effect of specific factors on the bacterial community owing to the covariance of environmental parameters. It is unlikely that some of the physical factors we measured directly affected bacterioplankton abundance. Ice thickness and PAR irradiance probably affected phytoplankton production and determined the quality and concentration of substrate suitable for bacterial utilization.

\section{Autumn}

Like previous Antarctic studies (Gibson et al. 1990, Leakey et al. 1996, Monticelli et al. 2003), we observed high bacterial abundance, production and proportions of active and intact bacteria for much of autumn. Concentrations of nitrogen-rich particulate matter were high at this time, and it is likely that grazing and autolysis during autumnal decline of the phytoplankton bloom released bioavailable DOC (Jumars et al. 1989, Agusti et al. 1998). The small increase in DOC at this time was likely a result of rapid utilization by bacteria (Pomeroy \& Weibe 2001).

The rapid decline in bacterial abundance at the end of March coincided with the peak abundance of microheterotrophs (I. Pearce et al. unpubl. data) and high concentrations of VLPs. Thus, like Gibson et al. (1990) and Monticelli et al. (2003), our results suggest the decline was a result of grazing and virus-induced lysis. We found no significant negative correlation between the abundance of bacteria and VLPs. However, highest VBRs and concentrations of VLPs occurred immediately prior to the autumn decline of bacteria, suggesting that rapid bacterial production in February enhanced the viral production (Maranger et al. 1994).

Winter

Bacterial productivity and abundance, especially that of active and intact cells, were low and progressively declined over winter. This was probably not a consequence of the limited availability of elemental nutrients (Odate \& Fukuchi 1995). Like Rivkin et al. (1991), we also suggest that it is unlikely a result of low temperature. We observed temperature to decline only $2.4^{\circ} \mathrm{C}$ over winter; rates of bacterial cell production and concentrations of active cells substantially increased in 
November before water temperature increased (Figs. 2B, 6 \& 7); and no significant difference was observed between rates of bacterial production in situ and ex situ in cabinets which were up to $3^{\circ} \mathrm{C}$ warmer than ambient in winter.

Like Tien et al. (1992), our data suggest that Antarctic bacteria experience substrate limitation in winter. We observed POC concentrations to progressively decline in winter owing to the absence of light for phytoplankton production (Tien et al. 1992, Pomeroy \& Weibe 2001, Delille 2004). The POC:PON ratio increased from around the Redfield ratio in autumn to values indicative of low nutrient detrital matter during winter. Although, like Scott et al. (2000), we found that concentrations of DOC varied little over the year, degradation of the low-nitrogen detrital matter remaining during winter would produce DOC of limited nutritional value. Thus, winter DOC probably comprised a refractory pool (Scott et al. 2000) that was largely unavailable to bacteria. Our results indicate phytoplankton production in summer was consumed and decomposed by heterotrophs over winter, which progressively exhausted suitable substrates for bacteria and resulting in low rates of bacterial production and concentrations of intact and active cells. In contrast, concentrations of total bacterial varied little with season. Like Yager et al. (2001), we conclude that their abundance is a poor index of bacterial activity in polar environments, especially during winter.

As in the seasonal comparison by Smith et al. (1992), we found that VLPs and VBRs declined >10-fold between autumn and winter. This decline may have been a result of the lower rates of bacterial production that increased generation times, decreased bacterial susceptibility to viral infection and/or decreased burst size of infected bacteria. Furthermore, viral infection of inactive bacteria may have resulted in lysogeny and acted as a sink for viruses (Maranger et al. 1994).

\section{Spring and summer}

Increasing concentrations of chl a during OctoberNovember coincided with the appearance of large ice algal diatoms in the water column, indicating that melting released aggregates of ice biota from the fast ice. Such aggregates sediment rapidly and contain a high proportion of attached bacteria (Riebesell et al. 1991, Meiners et al. 2004). We found that their transient appearance did not produce an increase in bacterial numbers or production in the water column.

A lag of approximately 1 mo occurred between the accumulation of new production (POC, PON and chl a) in mid to late November and increasing abundance of total bacteria. Other Antarctic studies reported a simi- lar lag in bacterial response to increased substrate availability, and attributed this lag to low temperature, low DOC fluxes and the release of nutrients during the collapse of phytoplankton blooms (e.g. Billen \& Becquevort 1990, Davidson \& Marchant 1992, Ducklow et al. 2001). However, like Kottmeier \& Sullivan (1988) and Stewart \& Fritsen (2004), we found that accumulation of new production coincided with increasing rates of bacterial cell production and the abundance of active and intact bacteria, rather than total bacteria numbers.

\section{CONCLUSIONS}

We showed that bacterial production and the abundance of intact, active and total bacteria (except those stained by DAPI) were correlated with concentrations of POC and PON but not DOC. Whether this was a result of nutritional dependence on particulate matter or rapid turnover of DOC remains unclear. However, our results indicate that new particulate production in late spring and summer initiates the bacterial bloom and supports most of the bacterial metabolism throughout the year in coastal Antarctic waters.

Acknowledgements. We gratefully acknowledge the assistance of G. Rowbottom for analysis of POC concentrations, C. Moy for guidance with DOC methods, R. van den Enden for assisting with analysis of Chlorophyll samples and the personnel at Davis Station for field and logistic support. E. Bell also acknowledges financial support from Deutsche Forschungsgemeinschaft overseas stipend (\#BE 2579/3-1) and the Scientific Committee for Antarctic Research, Prince of Asturias Fellowship (2003). Research was supported by the Australian Government's Cooperative Research Centres Programme through the Antarctic Climate and Ecosystems Cooperative Research Centre (ACE CRC) and the Australian Antarctic Science program (project 40).

\section{LITERATURE CITED}

Agustí S, Satta MP, Mura MP, Benavent E (1998) Dissolved esterase activity as a trace of phytoplankton lysis: evidence of high phytoplankton lysis rates in the northwest Mediterranean. Limnol Oceanogr 43:1836-1849

Archer SD, Leakey RJG, Burkill PH, Sleigh MA (1996) Microbial dynamics in coastal waters of East Antarctica: herbivory by heterotrophic dinoflagellates. Mar Ecol Prog Ser 139:239-255

Azam F (1998) Microbial control of oceanic carbon flux: the plot thickens. Science 280:694-696

Billen G, Becquevort S (1990) Phytoplankton-bacteria relationship in the Antarctic marine ecosystem. Polar Res 10: 245-253

Bjørnsen PK, Kuparinen J (1991) Growth and herbivory by heterotrophic dinoflagellates in the southern ocean, studied by microcosm experiments. Mar Biol 109:397-405

Boulos L, Prevost M, Barbeau B, Coallier J, Desjardins R 
(1999) LIVE/DEAD® BacLight ${ }^{\mathrm{TM}}$ : application of a new rapid staining method for direct enumeration of viable and total bacteria in drinking water. J Microbiol Methods 37: 77-86

Davidson AT, Marchant HJ (1992) Protist abundance and carbon concentration during a Phaeocystis dominated bloom at an Antarctic coastal site. Polar Biol 12:387-395

Davidson AT, Thompson PG, Westwood K, van den Enden R (2004) Estimation of bacterioplankton activity in Tasmanian coastal waters and between Tasmania and Antarctica using stains. Aquat Microb Ecol 37:33-45

del Giorgio PA, Gasol JM, Vaqué D, Mura P, Agustí S, Duarte CM (1996) Bacterioplankton community structure: protists control net production and the proportion of active bacteria in a coastal marine community. Limnol Oceanogr 41: $1169-1179$

Delille D (2004) Abundance and function of bacteria in the Southern Ocean. Cell Mol Biol 50:543-551

Ducklow H, Carlson C, Church M, Kirchman D, Smith D, Steward G (2001) The seasonal development of the bacterioplankton bloom in the Ross Sea, Antarctica 1994-1997. Deep-Sea Res II 48:4199-4221

Fuhrman JA (1999) Marine viruses and their biogeochemical and ecological effects. Nature 399:541-548

Gibson JAE, Garrick RC, Burton HR (1990) Seasonal fluctuation of bacterial numbers near the Antarctic continent. Proc NIPR Symp Polar Biol 3:16-22

Grossmann S, Dieckmann GS (1994) Bacterial standing stock, activity and carbon production during formation and growth of sea ice in the Weddell Sea, Antarctica. Appl Environ Microbiol 60:2746-2753

Guixa-Boixereu N, Vaque D, Gasol JM, Sanchez-Camara J, Pedros-Alio C (2002) Viral distribution and activity in Antarctic waters. Deep-Sea Res II 49:827-845

Heil P (2006) Atmospheric conditions and fast ice at Davis, East Antarctica: a case study. J Geophys Res 111:C05010, doi 10.1029/2005JC002904

Heinänen A, Raateoja M, Lahdes E, Leppänen JM (1997) Relationships between bacterioplankton, chl $a$ and temperature in Antarctic surface waters in summer. Polar Biol 18:62-69

Jeffrey SW, Wright SW (1997) Qualitative and quantitative HPLC analysis of SCOR reference algal cultures. In: Jeffrey SW, Mantoura RFC, Wright SW (eds) Phytoplankton pigments in oceanography: guidelines to modern methods. SCOR UNESCO, Paris, p 343-360

Jumars PA, Penry DL, Baross JA, Perry MJ, Frost BW (1989) Closing the microbial loop: dissolved carbon pathway to heterotrophic bacteria from incomplete ingestion, digestion and absorption in animals. Deep-Sea Res 36: 483-495

Karner M, Fuhrman JA (1997) Determination of active marine bacterioplankton: a comparison of universal 16S rRNA probes, autoradiography and nucleoid staining. Appl Environ Microbiol 63:1208-1213

Kirchman DL (2001) Measuring bacterial biomass production and growth rates from Leucine incorporation in natural aquatic environments. In: Paul JH (ed) Methods in microbiology. Marine microbiology, Vol 30. Academic Press, London, p 227-237

Kottmeier ST, Sullivan CW (1988) Sea ice microbial communities (SIMCO). 9. Effects of temperature and salinity on rates of metabolism and growth of autotrophs and heterotrophs. Polar Biol 8:293-304

Leakey RJG, Archer SD, Grey J (1996) Microbial dynamics in coastal waters of East Antarctica: bacterial production and nanoflagellate bacterivory. Mar Ecol Prog Ser 142:3-17
Legendre L, Legendre P (1983) Numerical ecology. Elsevier, Amsterdam

Mantoura RFC, Repeta DJ (1997) Calibration methods for HPLC. In: Jeffrey SW, Mantoura RFC, Wright SW (eds) Phytoplankton pigments in oceanography: guidelines to modern methods. SCOR UNESCO, Paris, p 407-428

Maranger R, Bird DF, Juniper SK (1994) Viral and bacterial dynamics in Arctic sea ice during the spring algal bloom near Resolute, N.W.T., Canada. Mar Ecol Prog Ser 111: 121-127

Marchant H, Davidson A, Wright S, Glazebrook J (2000) The distribution and abundance of viruses in the Southern Ocean during Spring. Antarct Sci 12:414-417

McManus (1993) Growth rates of natural populations of heterotrophic nanoplankton. In: Kemp PF, Sherr BF, Sherr EB, Cole JJ (eds) Handbook of methods in aquatic microbiology. Lewis Publishers, Ann Arbor, p 557-562

Meiners K, Brinkmeyer R, Granskog M, Lindfors A (2004) Abundance, size distribution and bacterial colonization of exopolymer particles in Antarctic sea ice (Bellingshausen Sea). Aquat Microb Ecol 35:283-296

Monticelli LS, La Ferla R, Maimone G (2003) Dynamics of bacterioplankton activities after a summer phytoplankton bloom period in Terra Nova Bay. Antarct Sci 15:85-93

Mordy CW, Penny DM, Sullivan CW (1995) Spatial distribution of bacterioplankton biomass and production in the marginal ice-edge zone of the Weddell-Scotia Sea during austral winter. Mar Ecol Prog Ser 122:9-19

Noble RT, Fuhrman JA (1998) Use of SYBR Green I for rapid epifluorescence counts of marine viruses and bacteria. Aquat Microb Ecol 14:113-118

Odate T, Fukuchi M (1995) Physical and chemical properties of surface water in the Southern Ocean in summer 1991/92. Proc NIPR Symp Polar Biol 8:77-85

Palethorpe B, Hayes-Gill B, Crowe J, Sumner M and 6 others (2004) Real-time physical data acquisition through a remote sensing platform on a polar lake. Limnol Oceanogr Methods 2:191-204

Pirker H, Pausz C, Stoderegger KE, Herndl GJ (2005) Simultaneous measurement of metabolic activity and membrane integrity in marine bacterioplankton determined by confocal laser-scanning microscopy. Aquat Microb Ecol 39:225-233

Pomeroy LR, Weibe WJ (2001) Temperature and substrates as interactive limiting factors for marine heterotrophic bacteria. Aquat Microb Ecol 23:187-204

Riebesell U, Schloss I, Smetacek V (1991) Aggregation of algae released from melting sea ice: implications for seeding and sedimentation. Polar Biol 11:239-248

Rivkin RB, Anderson MR, Gustafson DE (1991) Dynamics of bacterioplankton growth in McMurdo Sound, Antarctica: evidence for substrate sufficient growth. Antarct J US 26: 145-146

Rivkin RB, Anderson MR, Lajzerowicz C (1996) Microbial processes in cold oceans. 1. Relationship between temperature and bacterial growth rate. Aquat Microb Ecol 10: 243-254

Scott FJ, Davidson AT, Marchant HJ (2000) Seasonal variation in plankton, submicrometre particles and size fractionated dissolved organic carbon in Antarctic coastal waters. Polar Biol 23:635-643

Sherr BF, del Giorgio P, Sherr EB (1999) Estimating abundance and single-cell characteristics of respiring bacteria via the redox dye CTC. Aquat Microb Ecol 18:117-131

Smith DC, Azam F (1992) A simple economical method for measuring bacterial protein synthesis rates in sea water using $\left[{ }^{3} \mathrm{H}\right]$ leucine. Mar Microb Food Webs 6:107-109 
Smith DC, Steward GF, Azam F, Hollibaugh JT (1992) Virus and bacterial abundance in the Drake passage during January and August 1991. Antarct J US 27:125-127

Smith EM (1998) Coherence of microbial respiration rate and cell-specific bacterial activity in a coastal planktonic community. Aquat Microb Ecol 16:27-35

Smith EM, del Georgio PA (2003) Low fractions of active bacteria in natural aquatic communities? Aquat Microb Ecol 31:203-20

Stewart FJ, Fritsen CH (2004) Bacteria-algal relationships in Antarctic sea-ice. Antarct Sci 16:143-156

Tien G, Burgett J, Dore J, Geren M and 6 others (1992) Seasonal variability in microbial biomass in the Gerlache Strait: a feast-or-famine existence. Antarct J US 27: 166-167

Editorial responsibility: Gerhard Herndl,

Den Burg, Texel, The Netherlands
Yager PL, Connelly TL, Mortazavi B, Wommack KE, Bano N, Bauer JE, Opsahl S, Hollibaugh JT (2001) Dynamic bacterial and viral response to an algal bloom at subzero temperatures. Limnol Oceanogr 46:790-801

Yamaguchi N, Nasu M (1997) Flow cytometric analysis of bacterial respiratory and enzymatic activity in the natural aquatic environment. J Appl Microbiol 83:43-52

Zapata M, Rodríguez F, Garrido JL (2000) Separation of chlorophylls and carotenoids from marine phytoplankton: a new HPLC method using reversed phase $\mathrm{C}_{8}$ column and pyridine-containing mobile phases. Mar Ecol Prog Ser 195:29-45

Zweifel UL, Hagström Å (1995) Total counts of marine bacteria include a large fraction of non-nucleoid-containing bacteria (ghosts). Appl Environ Microbiol 61:2180-2185

Submitted: August 24, 2005; Accepted: December 14, 2006 Proofs received from author(s): March 16, 2007 